\title{
Enantioselective Organocatalytic Hydride Reduction
}

\author{
Stéphane G. Ouellet, Jamison B. Tuttle and David W. C. MacMillan* \\ Division of Chemistry and Chemical Engineering, California Institute of Technology, Pasadena, \\ California 91125

\section{Supporting Information}

General Information. Commercial reagents were purified prior to use following the guidelines of Perrin and Armarego. ${ }^{1}$ Non-aqueous reagents were transferred under nitrogen via syringe or cannula and purified according to the method of Grubbs. ${ }^{2}$ Organic solutions were concentrated under reduced pressure on a Büchi rotary evaporator. Chromatographic purification of products was accomplished using forced-flow chromatography on ICN 60 32-64 mesh silica gel and Iatrobeads $^{\circledR}$ according to the method of Still. ${ }^{3}$ Thin-layer chromatography (TLC) was performed on EM Reagents $0.25 \mathrm{~mm}$ silica gel $60-\mathrm{F}$ plates. Chromatograms were visualized by fluorescence quenching or by staining using either potassium permanganate or anisaldehyde stain.

${ }^{1} \mathrm{H}$ and ${ }^{13} \mathrm{C}$ NMR spectra were recorded on a Varian Mercury 300 Spectrometer, and are internally referenced to residual solvent signals. Data for ${ }^{1} \mathrm{H}$ NMR are reported as follows: chemical shift $(\delta \mathrm{ppm})$, multiplicity $(\mathrm{s}=$ singlet, $\mathrm{d}=$ doublet, $\mathrm{t}=$ triplet, $\mathrm{q}=$ quartet, $\mathrm{m}=$ multiplet), integration, coupling constant $(\mathrm{Hz})$ and assignment. Data for ${ }^{13} \mathrm{C}$ NMR are reported in terms of chemical shift. IR spectra were recorded on a Perkin Elmer Paragon 1000 spectrometer and are reported in terms of frequency of absorption $\left(\mathrm{cm}^{-1}\right)$. Mass spectra were obtained from the Caltech Mass Spectroscopy facility by electron ionization, chemical ionization, of fast atom/ion bombardment techniques. Gas liquid chromatography (GLC) was performed on Hewlett-Packard 6850 and 6890 Series gas chromatographs equipped with a splitmode capillary injection system and flame ionization detectors using a Bodman Chiraldex $\beta$-DM $(30 \mathrm{~m} \times 0.25 \mathrm{~mm})$, a Bodman Chiraldex $\Gamma$-TA $(30 \mathrm{~m} \times 0.25 \mathrm{~mm})$ or a Hydrodex-B-TBDAc $(50$ $\mathrm{m} \times 0.25 \mathrm{~mm}$ ) column as noted. High performance liquid chromatography (HPLC) was

\footnotetext{
${ }^{1}$ Perrin, D. D.; Armarego, W. L. F. Purification of Laboratory Chemicals; $3^{\text {rd }}$ ed., Pergamon Press, Oxford, 1988.

${ }^{2}$ Pangborn, A. B.; Giardello, M. A.; Grubbs, R. H.; Rosen, R. K.; Timmers, F. J. Organometallics 1996, $15,1518$.

${ }^{3}$ Still, W. C.; Kahn, M.; Mitra, A. J. J. Org. Chem. 1978, 43, 2923.
} 
performed on Hewlett-Packard 1100 Series chromatographs using a Chiralcel OD-H column (25 $\mathrm{cm})$ and OD-H guard $(5 \mathrm{~cm})$. Optical rotations were measured on a Jasco P-1010 polarimeter, and $[\alpha]_{\mathrm{D}}$ values are reported in $10^{-1} \mathrm{dg} \mathrm{cm}^{2} \mathrm{~g}^{-1}$; concentration (c) is in $\mathrm{g} / 100 \mathrm{ml}$.

\section{Preparation of the starting materials}

The following $\alpha, \beta$-unsaturated aldehydes have already been described in the literature: $(E)-3$ phenylbut-2-enal, ${ }^{4}(E)$-3-phenylpent-2-enal, ${ }^{5}(E)$-methyl 3-formyl-2-methylacrylate ${ }^{6}$.

(E)-3-cyclohexylbut-2-en-1-ol: To a $0{ }^{\circ} \mathrm{C}$ solution of $(E)$-ethyl 3-cyclohexylbut-2-enoate ${ }^{7}(1 \mathrm{~g}$, $5.09 \mathrm{mmol})$ in dry $\mathrm{Et}_{2} \mathrm{O}(10 \mathrm{~mL})$ was added a solution of lithium aluminum hydride $(5.10 \mathrm{~mL}$, $5.10 \mathrm{mmol}, 1 \mathrm{M}$ in $\mathrm{Et}_{2} \mathrm{O}$ ). After 5 minutes, the reaction mixture was neutralized by dropwise addition of THF solution followed by addition of a saturated solution of potassium sodium tartrate. The reaction mixture was stirred for 25 minutes, then diluted with $\mathrm{Et}_{2} \mathrm{O}$. The organic layer was separated and washed with water, dried over $\mathrm{Na}_{2} \mathrm{SO}_{4}$ and concentrated in vacuo to afford (E)-3-cyclohexylbut-2-en-1-ol as a colorless oil which was used directly in the following reaction.

(E)-3-cyclohexylbut-2-enal: To a solution of (E)-3-cyclohexylbut-2-enol (700 mg, $4.54 \mathrm{mmol})$ in dichloromethane $(11 \mathrm{~mL})$, cooled to $0{ }^{\circ} \mathrm{C}$, was added Dess-Martin periodinane $(2.11 \mathrm{~g}, 4.99$ mmol). The resulting suspension was warmed to $23{ }^{\circ} \mathrm{C}$ and stirred for approximately 30 minutes until the reaction was judged to be complete by TLC. The reaction mixture was poured into 50 mL of saturated aqueous $\mathrm{NaHCO}_{3}$ containing $\mathrm{Na}_{2} \mathrm{~S}_{2} \mathrm{O}_{3}(1 \mathrm{~g})$. This mixture was stirred vigorously until both layers became clear. The aqueous layer was extracted with $\mathrm{CH}_{2} \mathrm{Cl}_{2}(2 \times)$ and the combined organic layers were dried over $\mathrm{MgSO}_{4}$, filtered and concentrated in vacuo. The residue was purified by flash chromatography (25\% EtOAc/hexanes) to afford the title compound as a colorless oil (350 mg, $51 \%$ yield) that was a 5.2:1 mixture of $E: Z$ isomers. Major isomer: IR (film) 2929, 2854, 1729, 1674, 1640, 1450, 1383, 1198, 1164, 894, 850, $522 \mathrm{~cm}^{-1} ;{ }^{1} \mathrm{H}$ NMR $(300$

\footnotetext{
${ }^{4}$ Gandhi, R. P.; Walia, J. S.; Mukherji, S. M. J. Indian Chem. Soc. 1957, 34509.

${ }^{5}$ Schreiber, W. L.; Pittet, A. O.; Vock, M. H. J. Agr. Food Chem. 1974, 22, 269.

${ }^{6}$ Ishida, A.; Mukaiyama, T. Bull. Chem. Soc. Jpn. 1978, 51, 2077.

${ }^{7}$ Appella, D.H.; Yasunori, M.; Shantini, R.; Ferreira, E.M.; Buchwald, S.M. J. Am. Chem. Soc. 1999, $121,9473$.
} 
$\left.\mathrm{MHz}, \mathrm{CDCl}_{3}\right) \delta 10.05(\mathrm{~d}, 1 \mathrm{H}, J=7.9 \mathrm{~Hz} \mathrm{CHO}), 5.90(\mathrm{dq}, 1 \mathrm{H}, J=1.1,7.9 \mathrm{~Hz}, \mathrm{C}=\mathrm{CH}), 2.18(\mathrm{~d}$, $\left.3 \mathrm{H}, J=1.3 \mathrm{~Hz}, \mathrm{CH}_{3}\right), 2.09-2.02\left(\mathrm{~m}, 1 \mathrm{H}, \mathrm{CH}_{2} \mathrm{CHCH}_{2}\right), 1.87-1.70(\mathrm{~m}, 5 \mathrm{H}), 1.40(\mathrm{~m}, 5 \mathrm{H}) ;{ }^{13} \mathrm{C}$ NMR $\left(75 \mathrm{MHz}, \mathrm{CDCl}_{3}\right) \delta 191.9,168.8,125.8,48.4,31.4,31.2,26.3,26.1,26.0,16.1$; HRMS $\left(\mathrm{EI}^{+}\right)$exact mass calculated for $[\mathrm{M}]^{+}\left(\mathrm{C}_{10} \mathrm{H}_{16} \mathrm{O}\right)$ requires $\mathrm{m} / \mathrm{z} 152.1201$, found $\mathrm{m} / \mathrm{z} 152.1205$.

(E)-ethyl 3-cyclohexylpent-2-enoate: To $90 \mathrm{~mL}$ of EtOH, cooled to $0{ }^{\circ} \mathrm{C}$ in an ice bath, was added sodium metal $(1.64 \mathrm{~g}, 71.3 \mathrm{mmol})$. Once the metal had completely dissolved, triethyl phosphonoacetate $(15.9 \mathrm{~g}, 14.1 \mathrm{~mL}, 71.3 \mathrm{mmol})$ was added via syringe. The resulting solution was warmed to room temperature and stirred for 10 minutes. Cyclohexyl ethyl ketone (9.44 g, 9.20 $\mathrm{mL}, 67.3 \mathrm{mmol}$ ) was added and the solution stirred for $15 \mathrm{~h}$ at room temperature. The reaction was quenched in $100 \mathrm{~mL}$ ice water slurry. The aqueous layer was extracted with 200 $\mathrm{mL}$ of $\mathrm{Et}_{2} \mathrm{O}(3 \times)$. The combined organic layers were washed with $400 \mathrm{~mL}$ of brine, dried over $\mathrm{Na}_{2} \mathrm{SO}_{4}$, filtered and concentrated in vacuo. The product was purified by flash chromatography ( $1 \% \mathrm{Et}_{2} \mathrm{O} /$ pentane) to provide a clear oil $(2.5 \mathrm{~g}, 18 \%$ yield) that was a $3: 1$ mixture of $E: Z$ isomers. Major isomer: IR (film) 2977, 2929, 2854, 2360, 2341, 1716, 1638, 1448, 1203, 1147, 1042, 862, $750 \mathrm{~cm}^{-1} ;{ }^{1} \mathrm{H}$ NMR (300 MHz, $\left.\mathrm{CDCl}_{3}\right) \delta 5.58$ (s, 1H, C=CH), 4.15 (q, 2H, J = 4.1 Hz, $\left.\mathrm{OCH}_{2} \mathrm{CH}_{3}\right), 2.58\left(\mathrm{q}, 2 \mathrm{H}, J=7.4 \mathrm{~Hz}, \mathrm{CH}_{2} \mathrm{CH}_{3}\right), 1.81-1.62(\mathrm{~m}, 5 \mathrm{H}),, 1.35-1.11(\mathrm{~m}, 9 \mathrm{H}), 1.06(\mathrm{t}$, $\left.3 \mathrm{H}, J=2.2 \mathrm{~Hz}, \mathrm{CH}_{2} \mathrm{CH}_{3}\right) ;{ }^{13} \mathrm{C} \mathrm{NMR}\left(75 \mathrm{MHz} \mathrm{CDCl}_{3}\right) \delta 171.3,113.4,59.6,46.8,32.3,31.2$, 26.9, 26.8, 26.6, 26.3, 25.3, 14.5, 13.8; HRMS (EI $)$ exact mass calculated for $\left[\mathrm{M}^{+}\left(\mathrm{C}_{13} \mathrm{H}_{22} \mathrm{O}_{2}\right)\right.$ requires $m / z, 210.1620$, found $m / z, 210.1628$.

(E)-3-cyclohexylpent-2-enol: To a solution of $(E)$-ethyl 3-cyclohexylpent-2-enoate $(2.3 \mathrm{~g}, 10.9$ $\mathrm{mmol})$ in $\mathrm{Et}_{2} \mathrm{O}(22 \mathrm{~mL})$, was added lithium aluminum hydride $\left(1.0 \mathrm{M}\right.$ in $\mathrm{Et}_{2} \mathrm{O}, 10.9 \mathrm{~mL}, 10.9$ mmol) dropwise. After 5 minutes, the reaction mixture was slowly quenched with $1 \mathrm{~mL}$ of $\mathrm{MeOH}$ and poured into $100 \mathrm{~mL}$ of a saturated solution of potassium sodium tartrate. The aqueous layer was extracted with $100 \mathrm{~mL} \mathrm{Et}_{2} \mathrm{O}(3 \times)$. The combined organics were dried over $\mathrm{Na}_{2} \mathrm{SO}_{4}$, filtered and concentrated. The product was purified by flash chromatography (10\% EtOAc/hexanes) to provide a clear oil (1.59 g, 87\% yield) that was a 3:1 mixture of $E: Z$ isomers. Major isomer: IR (film) 3421, 2929, 2854, 1732, 1684, 1635, 1449, 1235, 1164, 864, $749 \mathrm{~cm}^{-1}$; ${ }^{1} \mathrm{H}$ NMR (300 MHz, $\left.\mathrm{CDCl}_{3}\right) \delta 5.33\left(\mathrm{t}, 1 \mathrm{H}, J=6.7 \mathrm{~Hz}, \mathrm{CHCH}_{2} \mathrm{OH}\right), 4.17(\mathrm{~d}, 2 \mathrm{H}, J=6.9 \mathrm{~Hz}$, $\mathrm{CH}_{2} \mathrm{OH}$ ), 2.07 (q, 2H, $\left.J=7.4 \mathrm{~Hz}, \mathrm{CH}_{2} \mathrm{CH}_{3}\right), 1.99$ to $1.63(\mathrm{~m}, 6 \mathrm{H}), 1.48-1.08(\mathrm{~m}, 6 \mathrm{H}), 0.97(\mathrm{t}$, 
$\left.3 \mathrm{H}, J=7.4 \mathrm{~Hz}, \mathrm{CH}_{2} \mathrm{CH}_{3}\right) ;{ }^{13} \mathrm{C}$ NMR $\left(75 \mathrm{MHz}, \mathrm{CDCl}_{3}\right) \delta 151.1,121.2,59.4,44.8,32.6,31.6$, 26.9, 26.7, 26.4, 23.1, 14.7; HRMS (EI $)$ exact mass calculated for $[\mathrm{M}]^{+}\left(\mathrm{C}_{11} \mathrm{H}_{20} \mathrm{O}\right)$ requires $\mathrm{m} / z$ 168.1514 , found $\mathrm{m} / \mathrm{z} 168.1520$.

(E)-3-cyclohexylpent-2-enal: To a solution of $(E)$-3-cyclohexylpent-2-enol (1.50 g, $8.91 \mathrm{mmol})$ in dichloromethane $(45 \mathrm{~mL})$, cooled to $0{ }^{\circ} \mathrm{C}$, was added Dess-Martin periodinane $(9.7 \mathrm{~g}, 22.9$ $\mathrm{mmol})$. The resulting suspension was warmed to room temperaure and stirred for approximately $2 \mathrm{~h}$ until the reaction was judged to be complete by TLC. The reaction was poured into $100 \mathrm{~mL}$ of saturated aqueous $\mathrm{NaHCO}_{3}$ containing $\mathrm{Na}_{2} \mathrm{~S}_{2} \mathrm{O}_{3}(3 \mathrm{~g})$. This mixture was stirred vigorously until both layers became clear. The aqueous layer was extracted with $\mathrm{CH}_{2} \mathrm{Cl}_{2}(2 \times)$ and the combined organic layers were dried over $\mathrm{MgSO}_{4}$, filtered and concentrated in vacuo. The residue was purified by flash chromatography $\left(5 \% \mathrm{Et}_{2} \mathrm{O} /\right.$ pentane) to afford the title compound ( $1 \mathrm{~g}, 68 \%$ yield) as a colorless oil that was a 3:1 mixture of $E: Z$ isomers. Major isomer: IR (film) 2927, 2746, 1668, 1622, 1450, 1189, 1124, $860 \mathrm{~cm}^{-1}$; ${ }^{1} \mathrm{H}$ NMR $\left(300 \mathrm{MHz}, \mathrm{CDCl}_{3}\right) \delta 10.04(\mathrm{~d}, 1 \mathrm{H}, J=$ $8.24 \mathrm{~Hz}, \mathrm{CHO}), 5.83$ (d, 1H, $J=8.24 \mathrm{~Hz}, \mathrm{C}=\mathrm{CH}), 2.61$ (q, 2H, $J=7.4 \mathrm{~Hz}, \mathrm{CH}_{2} \mathrm{CH}_{3}$ ), 2.07 (tt, $\left.1 \mathrm{H}, J=2.6,11.0 \mathrm{~Hz}, \mathrm{CH}_{2} \mathrm{CHCH}_{2}\right), 1.88-1.71(\mathrm{~m}, 5 \mathrm{H}), 1.41-1.15(\mathrm{~m}, 8 \mathrm{H}) ;{ }^{13} \mathrm{C} \mathrm{NMR}(75 \mathrm{MHz}$, $\left.\mathrm{CDCl}_{3}\right) \delta 191.8,175.2,124.9,46.2,31.9,26.5,26.3,26.0,25.9,24.2,15.4 ; \mathrm{HRMS}_{\left(\mathrm{EI}^{+}\right) \text {exact }}$ mass calculated for $[\mathrm{M}]^{+}\left(\mathrm{C}_{11} \mathrm{H}_{18} \mathrm{O}\right)$ requires $m / z$ 166.1358, found $m / z$ 166.1355.

(E)-ethyl 4-[tris-(1-methylethyl)silyloxy]-3-methylbut-2-enoate: To a suspension of sodium hydride $(60 \%$ dispersion in mineral oil, $1.58 \mathrm{~g}, 62.6 \mathrm{mmol})$ in dry toluene $(500 \mathrm{~mL})$ at $0{ }^{\circ} \mathrm{C}$, was added, dropwise, triethyl phosphonoacetate $(12.4 \mathrm{~mL}, 62.6 \mathrm{mmol})$ under an atmosphere of argon. After 30 minutes, 1-[tris-(1-methylethyl)silyloxy]-pentanone (12 g, $52.2 \mathrm{mmol})$ was diluted into toluene $(25 \mathrm{~mL})$ and added to the reaction mixture, which was then allowed to warm to room temperature over a period of $2 \mathrm{~h}$. The resulting mixture was washed with water, dried over $\mathrm{MgSO}_{4}$ and concentrated in vacuo. The residue was purified by flash chromatography (3\% $\mathrm{Et}_{2} \mathrm{O} /$ pentane) to afford ( $E$ )-ethyl 4-[tris-(1-methylethyl)silyloxy]-3-methylbut-2-enoate as a colorless oil (10.5 g, 67\% yield). Major isomer: IR (film) 2945, 2868, 1716, 1663, 1223, 1154, $1114 \mathrm{~cm}^{-1} ;{ }^{1} \mathrm{H}$ NMR (300 MHz, CDCl $) \delta 6.07$ (bs, 1H, CH), 4.21 (s, 2H, CH $\mathbf{H}_{2}$ OTIPS), 4.17 (q, $\left.2 \mathrm{H}, J=6.9 \mathrm{~Hz}, \mathrm{CH}_{3} \mathrm{CH}_{2} \mathrm{O}\right), 2.06\left(\mathrm{~s}, 3 \mathrm{H}, \mathrm{CCH}_{3}\right), 1.29\left(\mathrm{t}, 3 \mathrm{H}, J=7.8 \mathrm{~Hz}, \mathrm{CH}_{3} \mathrm{CH}_{2} \mathrm{O}\right), 1.09$ (m, 21H, TIPSO); ${ }^{13} \mathrm{C}$ NMR (75 MHz, $\left.\mathrm{CDCl}_{3}\right) \delta 167.0,157.0,113.2,67.2,59.4,17.9,15.3,14.3$, 
11.9; HRMS (EI $\left.{ }^{+}\right)$exact mass calculated for $[\mathrm{M}]^{+}\left(\mathrm{C}_{16} \mathrm{H}_{32} \mathrm{O}_{3} \mathrm{Si}\right)$ requires $\mathrm{m} / \mathrm{z}$ 300.2121, found $\mathrm{m} / \mathrm{z}$ 300.2125 .

(E)-3-[tris-(1-methylethyl)silyloxy]but-2-en-1-ol: To a $0{ }^{\circ} \mathrm{C}$ solution of $(E)$-ethyl 4-[tris-(1methylethyl)silyloxy]-3-methylbut-2-enoate $(5 \mathrm{~g}, 17.6 \mathrm{mmol})$ in $\operatorname{dry~}_{2} \mathrm{Et}_{2} \mathrm{O}$ was added a solution of lithium aluminum hydride (17.6 mL, $\left.17.6 \mathrm{mmol}, 1 \mathrm{M} \mathrm{in} \mathrm{Et}_{2} \mathrm{O}\right)$. After 30 minutes, the reaction mixture was neutralized by dropwise addition of THF followed by addition of a saturated solution of potassium sodium tartrate. The reaction mixture was stirred overnight and then diluted with $\mathrm{Et}_{2} \mathrm{O}$. The organic layer was separated and washed with water, dried over $\mathrm{MgSO}_{4}$ and concentrated in vacuo to afford (E)-3-[tris-(1-methylethyl)silyloxy]but-2-en-1-ol as a colorless oil which was used directly into the next reaction.

(E)-3-[tris-(1-methylethyl)silyloxymethyl]but-2-enal: To a room temperature solution of $(E)$ 3-[tris-(1-methylethyl)silyloxy]but-2-en-1-ol (crude from the previous step, assumed $17.6 \mathrm{mmol}$ ) in dichloromethane $(100 \mathrm{~mL})$ was added Dess-Martin periodinane $(9.7 \mathrm{~g}, 22.9 \mathrm{mmol})$. The resulting suspension was stirred for 60 minutes, until the reaction was judged to be complete by TLC. The reaction mixture was diluted with $\mathrm{Et}_{2} \mathrm{O}$ and a saturated aqueous solution of $\mathrm{NaHCO}_{3}$ containing $\mathrm{Na}_{2} \mathrm{~S}_{2} \mathrm{O}_{3}$ was added. This mixture was stirred vigorously until both layers became clear. The aqueous layer was extracted with $\mathrm{CH}_{2} \mathrm{Cl}_{2}(2 \times)$ and the combined organic layers were dried over $\mathrm{MgSO}_{4}$, filtered and concentrated in vacuo. The residue was purified by flash chromatography ( $5 \% \mathrm{Et}_{2} \mathrm{O} /$ pentane) to afford the title compound as a colorless oil ( $3.69 \mathrm{~g}, 82 \%$ yield). IR (film) 2944, 2867, 1681, 1464, 1384, $1123 \mathrm{~cm}^{-1} ;{ }^{1} \mathrm{H}$ NMR (300 MHz, $\left.\mathrm{CDCl}_{3}\right) \delta 10.09$ $(\mathrm{d}, 1 \mathrm{H}, J=8.3 \mathrm{~Hz}, \mathbf{C H O}), 6.28(\mathrm{dd}, 1 \mathrm{H}, J=1.5,8.4 \mathrm{~Hz}, \mathrm{CH}), 4.28(\mathrm{~d}, 2 \mathrm{H}, J=0.9 \mathrm{~Hz}$, C $\mathbf{H}_{2} \mathrm{OTIPS}$ ), 2.09 (d, 3H, $J=0.6 \mathrm{~Hz}, \mathrm{CH}_{3} \mathrm{C}$ ), 1.1 to 1.0 (m, 21H, TIPSO); ${ }^{13} \mathrm{C}$ NMR (75 MHz, $\left.\mathrm{CDCl}_{3}\right) \delta 191.2,161.6,124.1,67.0,18.0,14.1,11.9 ; \mathrm{HRMS}\left(\mathrm{EI}^{+}\right)$exact mass calculated for $[\mathrm{M}]^{+}$ $\left(\mathrm{C}_{14} \mathrm{H}_{28} \mathrm{O}_{2} \mathrm{Si}\right)$ requires $\mathrm{m} / \mathrm{z} 256.1859$, found $\mathrm{m} / \mathrm{z} 256.1862$.

General procedure for the enantioselective hydrogenation of enals: A colorless solution of (E)-3-phenylbut-2-enal (140 mg, $1 \mathrm{mmol})$ dissolved in $5 \mathrm{~mL}$ of chloroform $(0.2 \mathrm{M})$ was cooled to $-30{ }^{\circ} \mathrm{C}$ in a dry ice/acetone bath. To this solution was added the trichloroacetic acid salt of 
(R)-2-tert-butyl-3-methylimidazolidin-4-one (64 mg, $0.2 \mathrm{mmol}$ ) and Hantzsch ester (304 mg, 1.2 mmol). The resulting yellow suspension was stirred at $-30{ }^{\circ} \mathrm{C}$ until the reaction was determined to be complete by TLC, by which time the mixture was a light yellow homogeneous solution.

Workup procedure $\mathrm{A}$ : The reaction mixture was then diluted with $\mathrm{Et}_{2} \mathrm{O}$ and passed though a short pad of silica gel. The resulting solution was concentrated in vacuo and purified by flash chromatography (solvent noted) to provide the title compounds.

Workup procedure B: The cold reaction mixture was poured into a $10 \% \mathrm{HCl}$ solution and diluted with $\mathrm{Et}_{2} \mathrm{O}$. The organic layer was washed 4 times with $10 \% \mathrm{HCl}$ solution and once with a saturated aqueous solution of $\mathrm{NaHCO}_{3}$. The resulting solution was dried over $\mathrm{MgSO}_{4}$ and concentrated in vacuo. The residue was purified by flash chromatography (solvent noted) to provide the title compounds.

(S)-3-phenylbutanal (Table 3, entry 1). Prepared according to the general procedure from $(E)$ 3-phenylbut-2-enal (140 mg, $1 \mathrm{mmol})$ for $23 \mathrm{~h}$, using workup procedure A to provide the title compound as a colorless oil (127 mg, 91\% yield, 93\% ee) after purification by flash chromatography on Iatrobeads $^{\circledR}\left(20 \% \mathrm{Et}_{2} \mathrm{O} /\right.$ pentane $)$. The physical data were identical in all respects to those previously reported. ${ }^{8}$ The enantiomeric ratio was determined by GLC using a Bodman Chiraldex $\beta$-DM $(30 \mathrm{~m} \times 0.25 \mathrm{~mm})$ column $\left(90^{\circ} \mathrm{C}\right.$ isotherm, $\left.1 \mathrm{~mL} / \mathrm{min}\right) ;(R)$ isomer $t_{\mathrm{r}}$ $=38.6 \mathrm{~min}$ and $(S)$ isomer $t_{\mathrm{r}}=39.5 \mathrm{~min} .[\alpha]_{D}^{22}=+32.9^{\circ}(\mathrm{c}=1.00, \mathrm{EtOH})$.

(S)-3-phenylpentanal (Table 3, entry 3). Prepared according to the general procedure from (E)-3-phenylpent-2-enal (160 mg, $1 \mathrm{mmol}$ ) for $16 \mathrm{~h}$, using workup procedure A to provide the title compound as a colorless oil (119 mg, 74\% yield, 94\% ee) after purification by flash chromatography on Iatrobeads $^{\circledR}\left(10 \% \mathrm{Et}_{2} \mathrm{O} /\right.$ pentane $)$. The physical data were identical in all respects to those previously reported. ${ }^{9}$ The enantiomeric ratio was determined by GLC using a Bodman Chiraldex $\beta$-DM (30 m $\times 0.25 \mathrm{~mm})$ column $\left(95^{\circ} \mathrm{C}\right.$ isotherm, $\left.1 \mathrm{~mL} / \mathrm{min}\right) ;(R)$ isomer $t_{\mathrm{r}}$ $=42.8 \mathrm{~min}$ and $(S)$ isomer $t_{\mathrm{r}}=43.9 \mathrm{~min} .[\alpha]_{D}^{22}=+20.1^{\circ}(\mathrm{c}=1.00, \mathrm{EtOH})$

\footnotetext{
${ }^{8}$ Bull, S. D.; Davies, S. G.; Nicholson, R. L.; Sanganee, H. J.; Smith, A. D. Org. Biomol. Chem. 2003, $1,2886$.

${ }^{9}$ Berlan, J.; Besace, Y.; Pourcelot, G.; Cresson, P. Tetrahedron 1986, 42, 4757. (reported a rotation of $+2.1^{\circ}$ for a product that was $15 \%$ ee)
} 
(S)-3-cyclohexylbutanal (Table 3, entry 5). Prepared according to the general procedure from (E)-3-cyclohexylbut-2-enal (154 $\mathrm{mg}, 1 \mathrm{mmol}$ ) for $22 \mathrm{~h}$, using workup procedure A to provide the title compound as a colorless oil $(45.1 \mathrm{mg}, 91 \%$ yield, $96 \%$ ee) after purification by flash chromatography on silica gel $\left(10 \% \mathrm{Et}_{2} \mathrm{O} /\right.$ hexane $)$. The physical data were identical in all respects to those previously reported. ${ }^{10}$ The enantiomeric ratio was determined by GLC using a Bodman Chiraldex $\beta$-DM $(30 \mathrm{~m} \times 0.25 \mathrm{~mm})$ column $\left(80^{\circ} \mathrm{C}\right.$ isotherm, $\left.1 \mathrm{~mL} / \mathrm{min}\right) ;(R)$ isomer $t_{\mathrm{r}}$ $=70.6 \mathrm{~min}$ and $(S)$ isomer $t_{\mathrm{r}}=71.3 \mathrm{~min} .[\alpha]_{D}^{22}=+8.3^{\circ}(\mathrm{c}=1.00, \mathrm{EtOH})$.

(S)-3-cyclohexylpentanal (Table 3, entry 6). Prepared according to the general procedure from (E)-3-cyclohexylpent-2-enal ( $250 \mathrm{mg}, 1.50 \mathrm{mmol})$ for $24 \mathrm{~h}$, using workup procedure A to provide the title compound as a colorless oil (240.8 $\mathrm{mg}$, 95\% yield, 91\%ee) after purification by flash chromatography on silica gel $\left(10 \% \mathrm{Et}_{2} \mathrm{O} /\right.$ pentane). The enantiomeric ratio was determined by GLC using a Hydrodex-B-TBDAc $(50 \mathrm{~m} \times 0.25 \mathrm{~mm})$ column $\left(90{ }^{\circ} \mathrm{C}\right.$ isotherm, $\left.1 \mathrm{~mL} / \mathrm{min}\right)$; $(R)$ isomer $t_{\mathrm{r}}=35.2 \mathrm{~min}$ and $(S)$ isomer $t_{\mathrm{r}}=37.9 \mathrm{~min}$. IR (film) 2927, 2854, 1732, 1708, 1449, 1412, 1381, 1286, 1164, 954, $892 \mathrm{~cm}^{-1} ;{ }^{1} \mathrm{H}$ NMR $\left(300 \mathrm{MHz}, \mathrm{CDCl}_{3}\right) \delta 9.79$ (t, $1 \mathrm{H}, J=2.4 .3 \mathrm{~Hz}$, CHO), 2.44, (ddd, 1H, J = 2.1, 5.8, $16.4 \mathrm{~Hz}, \mathrm{CH}), 2.28(\mathrm{ddd}, 1 \mathrm{H}, J=2.7,7.2,16.2 \mathrm{~Hz}, \mathrm{CH}$ ), 1.82 to 1.61 (m, $5 \mathrm{H}), 1.47$ to 0.99 (m, $12 \mathrm{H}) ;{ }^{13} \mathrm{C} \mathrm{NMR}\left(75 \mathrm{MHz}, \mathrm{CDCl}_{3}\right.$ ) 203.9, 45.7, 40.3, 39.9, $30.4,29.2,26.74,26.69,26.67,24.3,11.8$; HRMS $\left(\mathrm{EI}^{+}\right)$exact mass calculated for $[\mathrm{M}]^{+}\left(\mathrm{C}_{11} \mathrm{H}_{20} \mathrm{O}\right)$ requires $m / z 168.1514$, found $m / z 168.1522 ;[\alpha]_{D}^{22}=+6.2^{\circ}\left(\mathrm{c}=1.03, \mathrm{CHCl}_{3}\right)$.

(S)-methyl 2-methyl-4-oxobutanoate (Table 3, entry 7). Prepared according to the general procedure from $(E)$-methyl 3-formyl-2-methylacrylate $(100 \mathrm{mg}, 0.781 \mathrm{mmol})$ for $26 \mathrm{~h}$ to provide the title compound (83\% yield, $91 \%$ ee). Yield was determined via ${ }^{1} \mathrm{H}$ NMR by comparison with an internal standard $(\mathrm{BnOMe})$. The physical data were identical in all respects to those previously reported. ${ }^{11}$ The enantiomeric ratio was determined by GLC using a Bodman Chiraldex $\Gamma$-TA $(30 \mathrm{~m} \times 0.25 \mathrm{~mm})$ column $\left(100{ }^{\circ} \mathrm{C}\right.$ isotherm, $\left.1 \mathrm{~mL} / \mathrm{min}\right) ;(S)$ isomer $t_{\mathrm{r}}=6.7 \mathrm{~min}$ and $(R)$ isomer $t_{\mathrm{r}}=7.7 \mathrm{~min} .[\alpha]_{D}^{22}=+1.4^{\circ}\left(\mathrm{c}=1.15, \mathrm{CHCl}_{3}\right)$.

\footnotetext{
${ }^{10}$ Tanaka, K.; Fu, G.C.. J. Org. Chem. 2001, 66, 8177. (reported a rotation of $+7.4^{\circ}$ for a product that was $74 \%$ ee)

${ }^{11}$ Kollar, L.; Consiglio, K.; Pino, P. J. Organomet. Chem. 1987, 330, 305. (reported a rotation of $+0.58^{\circ}$ for a product that was $10 \%$ ee)
} 
(S)-3-[tris-(1-methylethyl)silyloxymethyl]butanal (Table 3, entry 8). Prepared according to the general procedure from $(E)-3$-[tris-(1-methylethyl)silyloxymethyl]but-2-enal (245 mg, 1 mmol) for $72 \mathrm{~h}$, using workup procedure A to provide the title compound as a colorless oil (190 mg, $74 \%$ yield, $90 \%$ ee) after purification by flash chromatography on Iatrobeads ${ }^{\circledR}(10 \%$ $\mathrm{Et}_{2} \mathrm{O} /$ pentane). The enantiomeric ratio was determined by HPLC (the aldehyde was reduced and protected using $\mathrm{BzCl})$ on Chiralcel ${ }^{\circledR} \mathrm{OD}-\mathrm{H}(0.46 \mathrm{~mm} \times 25 \mathrm{~cm})$ isocratic $5 \% \mathrm{EtOH} / \mathrm{Hexanes}, 1$ $\mathrm{mL} / \mathrm{min}, 25^{\circ} \mathrm{C}$ ); $(S)$ isomer $t_{\mathrm{r}}=19.2 \mathrm{~min}$ and $(R)$ isomer $t_{\mathrm{r}}=22.2 \mathrm{~min}$. IR (film) 2944,2867 , 2716, 1728, 1464, 1385, $1101 \mathrm{~cm}^{-1} ;{ }^{1} \mathrm{H}$ NMR (300 MHz, $\left.\mathrm{CDCl}_{3}\right) \delta 9.80$ (t, $\left.1 \mathrm{H} \mathrm{J}=2.4 \mathrm{~Hz}, \mathrm{CHO}\right)$, $3.66(\mathrm{dd}, 1 \mathrm{H}, J=5.1,9.9 \mathrm{~Hz}$, TIPSOCH), $3.47(\mathrm{dd}, 1 \mathrm{H}, J=6.9,9.6 \mathrm{~Hz}$, TIPSOCH), $2.58(\mathrm{~m}, 1 \mathrm{H}$, CHCHO), 2.28 (m, 2H, MeCHCH), 1.06 (m, 21H, TIPSO), 0.97 (d, $\left.J=6.9 \mathrm{~Hz}, \mathrm{CH}_{3}\right) ;{ }^{13} \mathrm{C} \mathrm{NMR}$ $\left(75 \mathrm{MHz}, \mathrm{CDCl}_{3}\right) \delta 202.7,68.0,48.2,31.6,17.9,16.7,11.9 ; \mathrm{HRMS}_{\left(\mathrm{EI}^{+}\right) \text {exact mass calculated }}$ for $[\mathrm{M}-\mathrm{H}]^{+}\left(\mathrm{C}_{14} \mathrm{H}_{29} \mathrm{O}_{2} \mathrm{Si}\right)$ requires $m / z 257.1930$ found $m / z 257.1937 ;[\alpha]_{D}^{22}=-2.7^{\circ}(\mathrm{c}=1.07$, $\left.\mathrm{CHCl}_{3}\right)$.

(S)-3,4,4-trimethylpentanal (Table 3, entry 9). Prepared according to the general procedure, at room temperature, from $(E)$-3,4,4-trimethylpent-2-enal (70 $\mathrm{mg}, 0.56 \mathrm{mmol}$ ) for 5 minutes to provide the title compound (95\% yield, $97 \%$ ee). Yield was determined using ${ }^{1} \mathrm{H}$ NMR by comparison with an internal standard (BnOMe). The physical data were identical in all respects to those previously reported. ${ }^{12}$ The enantiomeric ratio was determined by GLC using a Bodman Chiraldex $\beta$-DM $(30 \mathrm{~m} \times 0.25 \mathrm{~mm})$ column $\left(60{ }^{\circ} \mathrm{C}\right.$ isotherm, $\left.1 \mathrm{~mL} / \mathrm{min}\right) ;(R)$ isomer $t_{\mathrm{r}}=19.29$ $\min$ and $(S)$ isomer $t_{\mathrm{r}}=20.32 \mathrm{~min} .[\alpha]_{D}^{22}=+29.3^{\circ}\left(\mathrm{c}=1.00, \mathrm{CHCl}_{3}\right)$.

\footnotetext{
${ }^{12}$ Berlan, J.; Besace, Y.; Pourcelot, G.; Cresson, P. Tetrahedron 1986, 42, 4757. (reported a rotation of $+3.4^{\circ}$ for a product that was $16 \%$ ee)
} 